\title{
Review \\ Micronutrients in Food Production: What Can We Learn from Natural Ecosystems?
}

\author{
Sarah M. Denton-Thompson * and Emma J. Sayer* $*$
}

Citation: Denton-Thompson, S.M.; Sayer, E.J. Micronutrients in Food Production: What Can We Learn from Natural Ecosystems? Soil Syst. 2022, 6, 8. https://doi.org/10.3390/ soilsystems 6010008

Academic Editors

Antonella Lavini and

Mohamed Houssemeddine Sellami

Received: 29 November 2021

Accepted: 7 January 2022

Published: 12 January 2022

Publisher's Note: MDPI stays neutral with regard to jurisdictional claims in published maps and institutional affiliations.

Copyright: (C) 2022 by the authors. Licensee MDPI, Basel, Switzerland. This article is an open access article distributed under the terms and conditions of the Creative Commons Attribution (CC BY) license (https:// creativecommons.org/licenses/by/ $4.0 /)$.
Lancaster Environment Centre, Lancaster University, Lancaster LA1 4YQ, UK

* Correspondence: s.denton-thompson@lancaster.ac.uk (S.M.D.-T.); e.sayer@lancaster.ac.uk (E.J.S.); Tel.: +44-(0)1524-510140 (E.J.S.)

\begin{abstract}
Soil micronutrients limit crop productivity in many regions worldwide, and micronutrient deficiencies affect over two billion people globally. Microbial biofertilizers could combat these issues by inoculating arable soils with microorganisms that mobilize micronutrients, increasing their availability to crop plants in an environmentally sustainable and cost-effective manner. However, the widespread application of biofertilizers is limited by complex micronutrient-microbe-plant interactions, which reduce their effectiveness under field conditions. Here, we review the current state of seven micronutrients in food production. We examine the mechanisms underpinning microbial micronutrient mobilization in natural ecosystems and synthesize the state-of-knowledge to improve our overall understanding of biofertilizers in food crop production. We demonstrate that, although soil micronutrient concentrations are strongly influenced by soil conditions, land management practices can also substantially affect micronutrient availability and uptake by plants. The effectiveness of biofertilizers varies, but several lines of evidence indicate substantial benefits in co-applying biofertilizers with conventional inorganic or organic fertilizers. Studies of micronutrient cycling in natural ecosystems provide examples of microbial taxa capable of mobilizing multiple micronutrients whilst withstanding harsh environmental conditions. Research into the mechanisms of microbial nutrient mobilization in natural ecosystems could, therefore, yield effective biofertilizers to improve crop nutrition under global changes.
\end{abstract}

Keywords: soil micronutrient availability; food crop production; microbial biofertilizer; microbial nutrient mobilization; plant micronutrient uptake; biofortification

\section{Introduction}

Human population growth and increasing levels of consumption are placing ever greater demands on farmers to increase crop production [1-3]. However, land availability for food production is limited, resulting in intensive agricultural practices that affect soil health and the wider environment [2,4]. It is therefore vital that global food production is increased sustainably to maintain soil health [4,5]. Nutrient availability in soils is one of the key factors underpinning food production [3,6]. As well as the more widely researched macronutrients, nitrogen $(\mathrm{N})$, potassium $(\mathrm{K})$ and phosphorus $(\mathrm{P})$, six trace elements are consistently described as important micronutrients for crop growth and yield: iron (Fe), zinc $(\mathrm{Zn})$, manganese $(\mathrm{Mn})$, molybdenum $(\mathrm{Mo})$, boron $(\mathrm{B})$, and copper $(\mathrm{Cu})$ [7-10]. In addition, cobalt $(\mathrm{Co})$ is beneficial to plants and plays a crucial role in nitrogen fixation in leguminous crops [9]. For simplicity, we refer henceforth to these seven trace elements as 'micronutrients'. Micronutrients in soils are largely derived from their parent material and required in minimal quantities by crops (i.e., $<1$ part per million). However, soil properties and conventional agricultural management practices, such as the use of higher yielding crop cultivars and the application of NPK inorganic fertilizers, can result in an insufficient micronutrient supply to crops [7-9]. A deficiency in even one of these nutrients can substantially reduce crop growth and yield, although an excessive supply, resulting in 
toxicity, can be equally detrimental $[7,8,10]$. In general, most plants have a narrow optimum micronutrient range, making it difficult to maintain the balance between deficiency and toxicity $[7,9,10]$. Thus, achieving a balanced supply of micronutrients in soils is essential for combatting human and animal dietary deficiencies in many parts of the world.

\subsection{Micronutrients and Hidden Hunger}

It is estimated that over two billion people worldwide suffer from 'hidden hunger', a deficiency in one or more micronutrients [11]. Deficiencies in Fe, $\mathrm{Zn}$ and Co (in the form of Vitamin B12) are amongst the most prevalent, especially in populations where diets mainly consist of cereals and legumes [12-14]. Similar micronutrient deficiencies were also noted in livestock and are most often seen in free-ranging herds with reduced supplementary feeding [15]. Hidden hunger in livestock and human populations that are heavily dependent upon crop-based foodstuffs demonstrates a clear need to address disparities in the micronutrient uptake and content of crops used in food production. Soil micronutrient content can be enhanced by fertilizer application, but this requires costly repeated applications with variable results and questionable environmental implications [16]. The excessive application of micronutrients would pose an equal, if not greater, environmental threat than over-fertilization with macronutrients, since toxicity thresholds for micronutrients are reached at considerably lower doses $[7,9,10]$. Therefore, to address micronutrient deficiency in crop production in a safe and sustainable manner, alternatives to inorganic fertilizer application are needed.

\subsection{Microbial Biofortification}

Biofortification is a promising avenue to address micronutrient deficiencies in agricultural crops. Crop biofortification encompasses a range of strategies that ultimately aim to improve the micronutrient content of crop plants, either by increasing micronutrient availability in arable soils, enhancing plant nutrient uptake, or both $[2,16,17]$. Plant breeding and genetic modification can create new cultivars with enhanced nutrient absorption, but these approaches are often costly, time-consuming and restricted by law [2,3]. By contrast, microbial biofortification is a recent strategy involving the enhancement of native soil microbial populations or the inoculation of arable soils with 'microbial biofertilizers' (hereafter biofertilizers) composed of plant growth-promoting microorganisms (PGPMs) [2,6,18,19]. Microbial biofortification focuses on enhancing the natural actions of microbes, which improve micronutrient availability and uptake, making it considerably more cost-effective, sustainable, and less environmentally damaging [2,16,20,21]. Microbial methods are also particularly effective for addressing micronutrient imbalances because they can be used to tackle both toxicity and deficiency [22-24].

Although microbial biofortification has evident theoretical benefits, its practical application proves difficult because the approach is underpinned by interactions among micronutrients, microbial communities, and crop species, which are still poorly understood $[3,19,20]$. Finding suitable microbial species for biofertilizers whilst ensuring that arable soil conditions support and enhance their action is particularly challenging. Thus, to ensure the widespread application of biofertilizers, we need to address several key knowledge gaps, such as effectiveness of biofertilizers under field conditions, the impacts of microbial or crop diversity, and the largely unknown effects of introduced microbial species on the native soil microbiota $[6,19,20]$. One way forward is to assess how plant-microbe interactions influence micronutrient availability in semi-natural ecosystems where environmental conditions, microbial communities and plant diversity are highly variable. We can then use this information to identify suitable combinations of microbiota and soil conditions for developing biofertilizers. Therefore, the primary aims of this review are to (i) assess the current state of seven micronutrients in food production, (ii) examine the interactions underpinning microbial biofortification in non-agroecosystems, and (iii) synthesize the state-of-knowledge on micronutrients to improve our overall understanding of microbial biofortification in food crop production. Although it is clear that many of the micronutrients 
reviewed here can also occur at toxic levels in some soils, our review focuses on micronutrient deficiency in arable soils, hence the exclusion of micronutrients such as chlorine and nickel, for which deficiency rarely occurs and is not as widely researched [25-27]. We focused on synthesizing the past and current literature to provide an integrative review of micronutrient biofertilizers (following [28]). Our literature search was carried out using Web of Science and Google Scholar, comprising (1) a general search for papers containing the terms 'micronutrient', 'agriculture', 'arable', 'biofertilizer', 'inoculant', 'soil' AND 'microb $^{* \prime}$ OR 'microorganism' followed by (2) a more specific search for each micronutrient by ecosystem (e.g., soil AND microb* AND iron AND grassland).

\section{Iron $(\mathrm{Fe})$}

Iron $(\mathrm{Fe})$ is the most abundant micronutrient and the fourth most abundant element overall in the Earth's crust [29]. Aside from parent material weathering, atmospheric deposition and the degradation of organic matter also provide soil $\mathrm{Fe}$ inputs to a lesser degree $[25,29,30]$. Iron is an essential component of human nutrition because it is involved in oxygen transport; in plants, $\mathrm{Fe}$ is required for enzyme production, photosynthesis, and $\mathrm{N}$ metabolism [9]. The total concentration of Fe in soils is generally sufficient to meet plant needs, but various soil properties can render the majority of Fe immobile, resulting in low Fe availability in c. $30 \%$ of soils worldwide [9,31]. Ensuring that crops receive sufficient Fe for optimum growth and yield is achieved by enhancing Fe availability, the efficiency of Fe absorption by crops, or a combination of both.

The availability of Fe in soils is governed by its chemical form, which in turn is dictated by numerous abiotic and biotic factors $[9,32,33]$. Iron primarily exists in ferrous (Fe II) and ferric (Fe III) forms, which can bind to clay fractions abiotically via cation exchange, or precipitate to form oxides, hydroxides and oxyhydroxides, which can render Fe unavailable under neutral or alkaline conditions $[25,29]$. Iron is widely used in biotic microbial redox reactions to yield energy for organic carbon degradation [25,34]. The reduction of ferric $\mathrm{Fe}(\mathrm{III})$ to ferrous $\mathrm{Fe}(\mathrm{II})$, which is more soluble and, therefore, readily available, primarily occurs under anaerobic conditions in water-saturated soils. However, under aerobic conditions, the oxidation of soluble Fe(II) to the more insoluble Fe(III) prevails, reducing Fe availability $[25,30,34]$. Consequently, agricultural management practices that influence soil $\mathrm{pH}$, redox potential, saturation, or aeration can affect the availability of $\mathrm{Fe}$ in soils.

\subsection{Fe Availability and Acquisition in Arable Soils}

The greater availability of $\mathrm{Fe}$ in acidic soils is one of the key issues in combatting Fe deficiencies in crops because low soil $\mathrm{pH}$ conditions are often not beneficial for crop plants and can reduce the availability of other nutrients [9]. The use of liming to counteract soil acidification is a common agricultural practice, but for every unit of increase in $\mathrm{pH}$ (between $\mathrm{pH} 4-9$ ) Fe solubility can decrease by up to a thousandfold [8]. Other agricultural practices such as tillage and irrigation can affect soil $\mathrm{pH}$ by altering aeration and water saturation, which can affect Fe mobilization or immobilization [8,35]. Consequently, in cultivated soils that are naturally calcareous, or where management practices alter soil $\mathrm{pH}$, soluble Fe concentrations may be suboptimal for meeting crop requirements $[32,33,36]$. The interaction between soil $\mathrm{pH}$ and soil organic matter (hereafter SOM) has a lesser but equally significant impact on Fe availability. Generally, soil Fe retention and availability increases with SOM content, which is problematic in arable soils where SOM is often heavily depleted [8,35,37]. Soil organic matter is both a source of Fe and of reducing agents, and hence the microbial mineralisation of SOM increases Fe concentrations and provides the necessary conditions for maximum Fe solubility [8]. Organic acids derived from $\mathrm{SOM}$ can increase $\mathrm{Fe}$ availability by reducing soil $\mathrm{pH}$ and by forming soluble $\mathrm{Fe}$ complexes [8,33]. However, other compounds in SOM can bind Fe to form increasingly insoluble organo-mineral complexes as soil $\mathrm{pH}$ increases $[8,9,33]$. Nonetheless, arable soils with low SOM content are more likely to be susceptible to Fe loss or fixation to stable compounds $[8,35,37]$. 
As well as the indirect impacts of alterations to soil conditions, arable management practices also directly influence Fe availability. In many countries, the application of inorganic fertilizers to correct Fe deficiency in crops has become increasingly common [9]. However, increasing Fe application may have a limited effect on heavily limed or naturally calcareous soils because the high soil $\mathrm{pH}$ favours Fe oxidation to insoluble forms. The application of organic fertilizers (e.g., farmyard manure) declined in recent decades with the widescale movement away from mixed farming [38], but preliminary evidence supports their use to combat Fe deficiency, which warrants further investigation [39]. Hence, soil management to increase Fe availability is possible, but when the necessary changes to soil conditions cannot be accomplished, deficiencies can instead be addressed by altering the nutrient acquisition strategies of plants and microbes.

\subsubsection{Fe Acquisition by Crops: Strategies and Efficiency}

Two factors can interfere with acquisition and use of Fe by crops, even when Fe availability in soils is not limiting. Firstly, plant breeding to increase crop yield and improve resistance to pathogens or pests can select for traits that increase the plant's micronutrient requirements, creating Fe deficiencies, even though soil Fe availability was considered sufficient for past cultivars [9]. Secondly, the application of herbicides such as glyphosate, diclofop-methyl and chlorsulfuron can interfere with root growth and Fe translocation from the roots to shoots and grain, resulting in plant Fe deficiency [33,40,41]. Plants employ two strategies to improve Fe acquisition under deficient conditions (Figure 1). Strategy I, used by nongraminaceous monocots and dicots (e.g., legumes), involves the release of protons into the rhizosphere, which increases soil acidity and mobilizes ferric Fe(III). Enzymes (chelate reductases) at the root-soil interface then reduce Fe(III) to ferrous Fe(II), which can be absorbed by the plant via ferrous transporters [29,42,43]. Strategy II plants are graminaceous monocots (e.g., grasses and cereal crops); the plants exude Fe-chelating organic substances (phytosiderophores), which form complexes with Fe(III) that plants can then absorb via plasma membrane transport systems without reduction $[29,42,43]$.

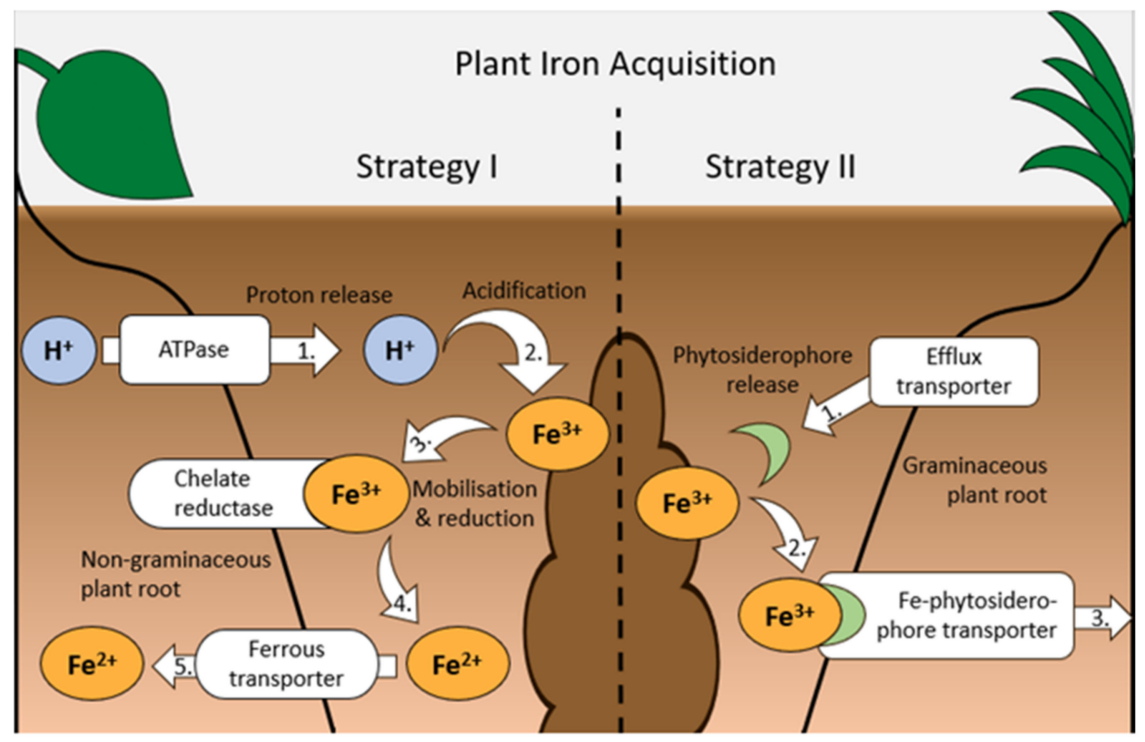

Figure 1. Diagram of the two iron (Fe) acquisition strategies employed by plants: orange ellipses show the chemical form of $\mathrm{Fe}$, blue circles represent hydrogen $\left(\mathrm{H}^{+}\right)$ions, white boxes with arrows indicate molecule transport points into/out of the root, and numbers indicate individual steps of the process (based on $[29,42,43]$ ).

Although strategy I plant species mobilize Fe by adjusting unfavourable soil $\mathrm{pH}$, this method is less effective in well-aerated calcareous soils and is considered less efficient overall than the method utilised by strategy II plants $[42,44]$. Phytosiderophores can be exuded in large quantities by strategy II plants and are capable of chelating Fe regardless 
of $\mathrm{pH}$. However, phytosiderophores are only released diurnally, with production peaking a few hours after dawn, and can be rapidly decomposed by certain microbial taxa $[42,44,45]$. Furthermore, when Fe availability is low, plants and soil microbes can compete for available $\mathrm{Fe}$, which has prompted increased research into microbial strategies for increasing $\mathrm{Fe}$ availability $[29,43,45]$.

\subsubsection{Fe Mobilization by Microbes}

Iron is widely used in microbial redox reactions to yield energy for organic carbon degradation $[33,45,46]$. The dissimilatory reduction of Fe(III) to Fe(II) occurs under anaerobic conditions, and microbes can also perform assimilatory Fe reduction under aerobic conditions both indirectly via acidification of the rhizosphere and directly by producing siderophores $[33,45,46]$. Microbial siderophores function in the same way as phytosiderophores but are considerably more efficient, possessing a greater stability and a higher affinity for forming Fe(III) complexes $[33,46,47]$. To date, over 500 types of microbial siderophores have been identified, with many microbial taxa capable of producing or utilising multiple types $[33,43,47]$. The strong affinity of microbial siderophores for Fe allows them to compete with plants by 'stealing' Fe from low-affinity phytosiderophores $[33,45,47]$. Despite this capability, numerous studies demonstrated a beneficial relationship between the presence of PGPMs and Fe accumulation by plants [43,48-50].

Microbial biofortification of Fe in plants can occur via several mechanisms: the presence of PGPMs can induce increased root hair proliferation and branching, trigger plant biochemical responses to Fe limitation, and prevent Fe acquisition by phytopathogenic microbes $[43,48-50]$. In addition, there is also considerable evidence that plants can utilise microbial siderophores, which appear to be dictated by the plants' Fe acquisition strategies. Chelate reductases in the roots of strategy I plants are capable of accepting Fe(III) complexes from microbial siderophores for reduction, producing freely available Fe(II), which can provide a significant fraction of plant Fe requirements $[33,42,48]$. The utilisation of microbial siderophores by strategy II plants is more variable due to the competition between microbial siderophores and phytosiderophores. However, some microbial siderophores, such as rhizoferrin, have an Fe affinity equal to phytosiderophores; therefore, they can act as an additional source of Fe to strategy II plants, either by direct uptake of Fe from microbial siderophores by the plant or (to a greater extent) Fe exchange from microbial siderophores to phytosiderophores $[33,42,50,51]$. Therefore, microbial biofortification could significantly improve crop Fe acquisition if the selected PGPMs induce plant responses to Fe limitation or produce siderophores that promote plant Fe uptake.

\subsection{Fe in Natural Ecosystems}

Studies of biotic interactions with Fe in (semi-)natural ecosystems provide valuable insights into microbial taxa suitable for biofertilizers because the soils, microbial communities, and vegetation have been much less affected by human activities than in agroecosystems [35,37,52]. Forest soils received considerable attention for bioprospecting, most likely because they possess high microbial diversity [35,37,52], which increases the likelihood of finding suitable PGPMs. Numerous dissimilatory Fe-reducing bacterial taxa isolated from tropical forest soils are already acclimated to periodic waterlogging [53-55], providing an insight into how microbial Fe reduction may be influenced by soil aeration or water saturation. Fluctuations in Fe redox reactions in tropical forest soils closely follow rainfall patterns, with long dry periods leading to increased aeration and decreased Fe reduction [56]. Thus, biofertilizers based on taxa from tropical soils may be best applied immediately after rainfall or irrigation to maximise Fe reduction, and thus crop Fe acquisition. However, since many tropical forest soils are rich in $\mathrm{Fe}$, microbial taxa isolated from tropical soils might not be suitable for soils with limited Fe availability. Instead, taxa capable of siderophore production under Fe-limited conditions may prove more effective. Siderophore-producing microbes isolated from the soils of montane forest ecosystems are not only capable of increasing Fe availability and acquisition but can do so even when exposed to extreme envi- 
ronmental stress $[57,58]$. Although research into the utilisation of these microbial species as biofertilizers only began in the last decade, preliminary results indicate significant potential for their application in combatting Fe deficiency in arable crops $[57,58]$.

Other ecosystems exposed to extreme or fluctuating temperatures are potential sources of microbial taxa for novel biofertilizers, especially for use in agroecosystems in colder climates. Bacterial strains capable of producing siderophores at both low (e.g., $\left.4{ }^{\circ} \mathrm{C}\right)$ and relatively high (e.g., $30^{\circ} \mathrm{C}$ ) temperatures were isolated from cold deserts and glaciers [59,60]. Surprisingly, grassland ecosystems received less attention as potential sources of biofertilizers, although siderophore-producing fungal species may be sourced from grassland soils [61]. Many fungal species from Ascomycota and Basidiomycota can produce the siderophore ferricrocin, which plants can utilise to obtain Fe; however, some of these fungal species are pathogenic, and so a careful separation from PGPM species is required [61].

Finally, research into the degradation of SOM in natural ecosystems could be informative because microbial SOM mineralisation under water-saturated conditions releases Fe from organic complexes and increases the availability of soluble organic carbon $[54,56]$. As the amount of SOM in agroecosystems is often limited [35,37,42], the effects of organic matter applications on Fe availability in arable soils are still unclear. Nonetheless, studies in forest and grassland soils demonstrate that Fe reduction increases with the availability of labile carbon due to its stimulatory effects on microbial activity [53,54,62]. Even at higher soil $\mathrm{pH}, \mathrm{Fe}$ reduction can be further enhanced by regular additions of organic carbon, especially under anaerobic conditions [53,54]. As SOM can also act as a source of soluble Fe, the addition of organic fertilizers to arable soils could significantly and sustainably increase Fe availability to crops, with or without biofertilizers.

\section{Zinc (Zn)}

Zinc $(\mathrm{Zn})$ deficiency is now considered a global-scale crisis, and correcting its low availability in arable soils has become a widely researched topic [9,63-65]. In plants, $\mathrm{Zn}$ is essential for growth $[9,65]$, heat stress tolerance [63], pathogen resistance, and reproduction $[64,66]$. In humans, $\mathrm{Zn}$ is a vital component of DNA, RNA and over 300 bodily enzymes, with evidence also suggesting a role in gene expression [63,67]. However, many countries reported extensive $\mathrm{Zn}$ deficiency in arable soils [63], which not only leads to yield reductions of up to $80 \%$, but to widespread Zn deficiency in approximately one third of the global human population, especially in populations dependent on cereal-based diets $[64,68]$.

Zinc levels in soils are maintained by atmospheric inputs, which generally exceed outputs or losses via leaching and biological uptake $[25,69]$. However, although the total $\mathrm{Zn}$ concentrations in most soils appear sufficiently high to meet plant needs, approximately $90 \%$ of $\mathrm{Zn}$ in soils worldwide is thought to exist in a form unavailable to plants $[25,64,66]$, and c. $30-50 \%$ of soils possess insufficient available $\mathrm{Zn}$ to meet plant requirements $[25,66,70]$. Unlike some other micronutrients, $\mathrm{Zn}$ can persist in numerous free ionic forms and complexes with other metals, as well as in crystalline forms bound to clay fractions and as a component of insoluble or soluble (organic) complexes. As such, soil type and soil properties also have a strong impact on $\mathrm{Zn}$ levels, with lower $\mathrm{Zn}$ concentrations in sandy soils and higher concentrations in organic and calcareous soils $[25,69]$. Zinc availability declines with increasing $\mathrm{pH}$ due to increased fixation in soil minerals and the formation of insoluble $\mathrm{Zn}$ compounds (e.g., hydroxides, calcium zincate) in soils with $\mathrm{pH}>7.5$. Therefore, in highly calcareous or heavily limed soils, $\mathrm{Zn}$ availability and uptake by crops is greatly limited $[9,25,71]$. Aside from liming, several other arable management practices can also reduce $\mathrm{Zn}$ availability $[23,63]$ : excessive $\mathrm{P}$ fertilization can interfere with plant $\mathrm{Zn}$ acquisition and applying organic material with a high ligand content can reduce $\mathrm{Zn}$ availability via the formation of insoluble organo-mineral complexes $[9,66,70]$. Furthermore, flooding (e.g., in rice paddies) and the selection of crop cultivars with high Zn-demand can also result in insufficient $Z n$ availability $[9,63,66]$.

Although plants are capable of chelating $\mathrm{Zn}$ in the same way as Fe through rhizospheric acidification and the production of phytosiderophores, these plant strategies are 
often insufficient for addressing Zn deficiencies [19,63,64]. Consequently, the application of inorganic $\mathrm{Zn}$ fertilizers is common practice in many countries, with one application theoretically providing enough $\mathrm{Zn}$ to last for up to six crop rotations [63]. However, due to the rapid fixation and immobilization of $\mathrm{Zn}$ in most soils, only $1-20 \%$ of the applied $\mathrm{Zn}$ is absorbed by crops, rendering this approach financially costly and environmentally unsustainable $[63,71,72]$. Therefore, research efforts turned to developing biofertilizers that can mobilize insoluble $\mathrm{Zn}$ pools already present in soils $[3,63,66]$.

\subsection{Zn Mobilization by Microbes}

The microbial biofortification of crops with $\mathrm{Zn}$ received extensive research and is hailed as the most promising solution to $\mathrm{Zn}$ deficiency in arable agriculture [3]. The crop uptake of $\mathrm{Zn}$ via microbial siderophores is far less difficult to implement than Fe uptake $[3,19,66]$; numerous bacterial strains, as well as arbuscular mycorrhizal fungi (AMF) and fungal species from the genus Trichoderma, can acidify the rhizosphere through organic acid or proton release and produce siderophores that enable them to solubilize $\mathrm{Zn}[3,19,21,64]$. Furthermore, endophytic fungal species such as AMF produce hyphae capable of physically accessing $\mathrm{Zn}$ pools that plant roots would otherwise be unable to reach; the chelated $\mathrm{Zn}$ is absorbed into the hyphal network and transported directly back to the plant's roots $[3,19,64]$. Due to the efficiency and effectiveness of microbial $\mathrm{Zn}$ solubilization, the application of biofertilizers successfully alleviated Zn deficiency in many crops $[3,64,66]$.

In soils where $\mathrm{Zn}$ deficiency is caused by low concentrations of total $\mathrm{Zn}$ rather than low availability, the application of $Z n$ fertilizers in combination with biofertilizers prevents the applied $\mathrm{Zn}$ from being instantly immobilized [73-75]. Using this dual application, farmers can biofortify their crops whilst applying less $\mathrm{Zn}$, which is more financially and environmentally sustainable $[75,76]$. However, the highly variable sensitivity of microbes to $\mathrm{Zn}$ toxicity and variable microbial responses among taxa can limit the co-application of biofertilizers and conventional $\mathrm{Zn}$ fertilizers [77,78]. Zinc nano-fertilizers were recently suggested as a more sustainable alternative, with successful crop Zn deficiency remediation at low application rates, and either neutral or positive impacts on native soil microbiota [79-82]. In summary, the co-application of $\mathrm{Zn}$ nano-fertilizers with biofertilizers could present a way to alleviate crop $Z n$ deficiencies, while maintaining healthy soil microbial communities. However, although numerous $\mathrm{Zn}$-solubilizing microbes were identified, some strains may be more effective than others under given environmental conditions. Therefore, natural ecosystems remain an important potential source for new and alternative Zn-biofortifying microbes.

\subsection{Lessons for Zn Biofortification}

As $\mathrm{Zn}$ is one of the most common heavy metals in municipal waste, sewage, and composted residues [83,84], research investigating soil Zn concentrations in semi-natural ecosystems mostly focuses on issues of contamination, and studies of $\mathrm{Zn}$-solubilizing microbes are few and far between. However, two studies offer some valuable insights into the efficacy of biofertilizers. A study of the effects of historical sewage sludge application on microbial communities in grassland and arable soils showed that altered microbial community structure was associated with elevated soil Zn concentrations, even 11 years after the final sewage application [85]. Hence, substantial past $\mathrm{Zn}$ fertilizer additions to arable soils could affect the effectiveness of biofertilizers, a potential issue that warrants further investigation. A study in desert soils identified two bacterial strains in the roots of chickpea (Cicer arietinum L.) plants, which were capable of significantly increasing plant $\mathrm{Zn}$ uptake [86]. Bacteria sourced from such a harsh environment could be used to create biofertilizers with greater resistance to extreme temperatures and drought. Hence, the bioprospecting of semi-natural ecosystems may yield further $\mathrm{Zn}$-solubilizing species to create biofertilizers for arable food production under challenging environmental conditions [86]. 


\section{Boron (B) and Molybdenum (Mo)}

The co-limitation by boron (B) and molybdenum (Mo) is common in leguminous crops [87-89]. Food crop deficiencies in B and Mo occur worldwide, but leguminous (e.g., beans, peas, lentils) and other dicotyledon crops (e.g., sunflower, oilseed rape) are typically more prone to $B$ and Mo deficiency than cereal crops, whereas fruiting tree and vine species are susceptible to $B$ deficiency alone $[9,89,90]$. Boron deficiency can disrupt crop growth, reduce crop yield, elongate roots, and reduce root nodulation in legumes $[9,89,91]$. However, the biological function of B in humans is yet to be established, and B deficiency is rarely (if ever) recorded [92]. Molybdenum deficiency in crops also disrupts growth and reduces yield, affecting $\mathrm{N}$ fixation and the production of multiple enzymes, including those that facilitate P uptake $[9,93,94]$. The deficiency of Mo in humans can occur and is linked to oral, throat and gastric cancers; however, its prevalence is extremely low $[95,96]$. Therefore, in the context of food production, B and Mo deficiencies are a more significant issue for crop growth and yield than for human nutrition.

Soil $\mathrm{pH}$ is the primary factor controlling the availability of $\mathrm{B}$ and Mo; Mo availability increases with $\mathrm{pH}$, whereas $\mathrm{B}$ availability tends to increase up to $\mathrm{pH} 7$, and then declines [30,97]. Under acidic conditions, B is highly mobile and prone to leaching, but under alkaline conditions it forms insoluble complexes with SOM and (oxy-)hydroxides or becomes fixed onto clay fractions $[9,25,30]$. Conversely, $\mathrm{Mo}$ is readily available in a $\mathrm{pH}$ range of 7.5-9 but becomes fixed to SOM and Fe hydroxides under acidic conditions $[9,25,98]$. Therefore, B deficiency is typically observed in calcareous or heavily limed soils and sandy soils prone to leaching, whereas Mo deficiency is common in acidic and heavily leached soils. These differences in the availability of $B$ and Mo create issues for alleviating the deficiencies of one nutrient in arable soils, whilst controlling for the toxicity of the other. However, low B and Mo availability in arable soils is a more common and widespread issue than toxicity $[9,89,98]$. Since B and Mo availability is primarily controlled by soil $\mathrm{pH}$ and leaching, arable management practices affecting these two soil conditions, such as liming, irrigation and tillage, can affect their availability $[9,25,98-100]$. Low SOM content in conventional arable systems reduces the availability of both nutrients, and thus the addition of organic matter can increase both B and Mo availability via the formation of soluble complexes $[25,99,101]$.

\subsection{Microbial B and Mo Requirements}

Soil microbes facilitate the release of B and Mo through organic matter degradation and mobilization from insoluble complexes [102]. Bacteria and fungi require B and Mo to produce numerous enzymes, and these micronutrients also play very specific roles in the symbiotic relationship between leguminous plant species and rhizobial bacteria [89,102], in which the rhizobia fix and convert atmospheric $\mathrm{N}$ to ammonia $[91,103,104]$. Rhizobia infect the roots of legumes by suppressing the plant's pathogenic defences using polysaccharides attached to their cell surface. In B-deficient rhizobia, polysaccharide synthesis is reduced by approximately $65-80 \%$, which hinders infection and limits the successful establishment of the symbiotic relationship $[91,105]$. Furthermore, as Mo is an essential component of nitrogenase, the $\mathrm{N}$-fixing enzyme produced by rhizobia, Mo-limited bacteria fail to supply $\mathrm{N}$ to the plant $[95,98,106]$. Hence, microbial deficiency in either of these micronutrients can substantially reduce leguminous crop growth and yield $[89,98]$.

\subsection{Management of $B$ and Mo in Arable Soils}

The application of $B$ and Mo as inorganic fertilizers was used to correct deficiencies in arable soils and food crops worldwide [9]. Inorganic B can be applied by seed priming, or directly to soils or foliage. Seed priming is cost-effective but less successful for fortification, whereas foliar application corrects deficiency in crops but not in soil microbes $[9,100,107]$. Soil B application is very effective for increasing crop yield, fortifying grain, and increasing microbial activity and abundance under optimal soil conditions, but the quantities and chemical form of the applied B must be carefully monitored to prevent toxicity $[100,102,108]$. 
Additionally, in calcareous or heavily limed soils, most of the applied inorganic B is likely to rapidly become unavailable, rendering this method both costly and ineffective $[100,101]$. Inorganic Mo fertilizer is often applied either in combination with, or as an accidental contaminant of, other fertilizers, but can also be applied separately as a foliar spray $[9,109]$. Foliar Mo spray can fortify leguminous crops and enable symbiotic translocation of Mo to the rhizobia colonizing their roots, increasing root nodulation by more than 50\% [98]. However, in acidic soils, foliar application is much less effective and does not provide Mo for free-living microbes in the soil, which may be important for non-leguminous crops $[98,110]$.

Low B and Mo availability in soils might be best alleviated by combining inorganic fertilizers with biofertilizers. For example, the co-application of inorganic B fertilizer and biofertilizers produced the greatest increase in broccoli growth, yield, and weight [111]. The joint application of inorganic Mo fertilizer and biofertilizers can boost soil microbial activity, increase yield, and quadruple root nodulation in leguminous crops [88,112,113]. Thus, the co-application of biofertilizers with inorganic fertilizers offers a promising way to combat B and Mo deficiencies in both food crops and soil microbial communities. However, few (if any) microbial taxa were found to be capable of increasing B and Mo availability or uptake in arable soils without the co-addition of inorganic fertilizers.

\subsection{B and Mo in Natural Ecosystems}

Given the clear requirements of soil microorganisms for both micronutrients, bioprospecting in natural ecosystems could yield microbial taxa suitable for application as biofertilizers $[109,114,115]$. Studies relating to the microbial usage and mobilization of B in natural ecosystems are limited and have yet to yield B-mobilizing microbial taxa [57,58]. Research into Mo-mobilizing taxa in natural ecosystems is also limited, but it is possible that free-living, N-fixing microbes in forest soils are capable of releasing chelating agents to acquire Mo for nitrogenase production [116], and there is evidence that Azotobacter vinelandii produces a Mo-chelating siderophore or 'molybdophore' [117]. Hence, there is still much work to be carried out to identify and characterize the microbial acquisition of $B$ and Mo in natural ecosystems, but such research could yield microbial strains suitable for use as biofertilizers.

\section{Manganese (Mn)}

Manganese $(\mathrm{Mn})$ is essential for most living organisms and is required by all plants for photosynthesis, chloroplast breakdown and synthesis, and enzyme structure and function $[25,118,119]$. In humans, $\mathrm{Mn}$ is needed for reproduction, carbohydrate and lipid metabolism, and neurological functioning [120]. Crops grown for food production are the primary source of Mn for humans, providing over $50 \%$ of our dietary intake $[118,121]$. Although Mn deficiency has not yet been observed in the human population [120], it occurs in c. $10 \%$ of arable soils worldwide; global fruit, cereal, and certain vegetable crops are all prone to Mn deficiency, which causes interveinal leaf chlorosis and necrotic spotting, reduced tillering, the inhibition of root growth, stunted plant growth and suboptimal nutrient assimilation $[9,25,118,121]$. As such, correcting Mn deficiency is vital for maintaining crop yields, food production and human Mn intake [118,121].

Manganese is the fifth most abundant metal and twelfth most abundant element in soils, and thus the total concentrations are often sufficient to meet plant requirements [120]. However, Mn availability decreases at soil $\mathrm{pH}>7.5$ as it adsorbs strongly into various (hydr-)oxides, clay fractions, organic compounds, and calcium carbonate [25]. Consequently, Mn deficiency typically occurs in arable crops grown in calcareous or heavily limed soils [9,25,118,121]. However, even under alkaline conditions, Mn-containing organomineral and anionic complexes can remain relatively soluble and contribute to Mn availability for plants and microbes [25]. In soils with $\mathrm{pH}<5.5, \mathrm{Mn}$ adsorption is greatly reduced and its availability to plants and microbes increases $[25,119]$. However, soil aeration also strongly influences Mn availability by affecting the microbial oxidation or reduction of 
Mn. Under aerobic conditions, the oxidation of Mn(II) to Mn(III), and then to Mn(IV) by bacteria and fungi, reduces its availability; under anaerobic conditions, Mn is reduced, which increases its availability $[25,122]$. Hence, arable management practices that alter soil $\mathrm{pH}$ or aeration (e.g., reduced organic matter application, tillage, and irrigation) can cause substantial losses of Mn by leaching [25]. Finally, the application of herbicides, such as glyphosate, can inhibit crop acquisition of Mn [9,25,118,121]. Hence, arable management can substantially influence Mn availability by altering abiotic and biotic soil factors.

When soil Mn availability becomes limiting, crop plants employ alternative measures to acquire sufficient Mn for their biological functions [123,124]. Plants can acquire Mn in much the same way as Fe, either via acidification of the rhizosphere (strategy I) or the release of phytosiderophores (strategy II) [123,124]. However, Mn mobilization by organic acids released into the rhizosphere is relatively low [123] and phytosiderophore affinity for $\mathrm{Mn}$ is weak; therefore, other micronutrients are more likely to be chelated in place of Mn [124]. Consequently, the plant acquisition of $\mathrm{Mn}$ is heavily dependent on soil $\mathrm{pH}$, aeration, and microbial Mn reduction, and agricultural intervention is required to fortify crops with $\mathrm{Mn}$ in arable soils where these factors are unfavourable [25,71,123].

\subsection{Management of Mn in Arable Soils}

The use of inorganic fertilizers has become common practice for correcting Mn deficiency in arable crops worldwide $[9,118,121]$. The soil application of inorganic $\mathrm{Mn}$ is perhaps most prevalent due its low cost and ease of implementation, but foliar application is far more effective for supporting crop growth, increasing yield, and fortifying grains with Mn, although multiple applications are required [9,121]. Seed coating (with Mn) and osmopriming (seed soaking in Mn solution) were trialled in rice and wheat crops, with coating being better for crop growth and osmopriming boosting yields close to or greater than foliar applications $[118,121]$. However, the effectiveness of all Mn application methods varies depending on the target crop $[118,121]$, and not all methods are affordable for farmers on lower incomes [9]. Furthermore, aside from foliar application, the uptake of inorganic Mn fertilizers by crops can still be greatly limited when glyphosate is applied [9]. The inclusion of leguminous crops, legume intercropping, or legumes in herbal ley rotations can increase $\mathrm{Mn}$ availability for subsequent arable crops by reducing soil $\mathrm{pH}$; however, these practices have fallen out of favour in many countries $[1,125,126]$. Overall, the widespread application of inorganic $\mathrm{Mn}$ fertilizers is often financially unsustainable and frequently ineffective. However, inorganic Mn fertilizers may be unnecessary where total soil Mn concentrations are high but inaccessible to plants, since biofertilizers could substantially increase plant access to Mn.

Biofertilizers capable of fortifying crops with Mn can be split into two groups: Mnmobilizing fungal taxa and Mn-reducing rhizobacteria. Crop inoculation with AMF or fungal taxa applied as biopesticides is thought to aid Mn availability and acquisition by acidifying the rhizosphere and promoting numerous plant growth traits $[127,128]$, although evidence for its effectiveness is mixed. Inoculation with fungal taxa alone does not significantly increase plant Mn acquisition [127], and the co-inoculation of AMF and Mn-reducing rhizobacteria can even reduce Mn uptake, possibly because AMF suppress Mn-reducing rhizobacterial populations [128,129]. However, the inoculation with Mnreducing rhizobacteria alone can greatly improve Mn availability and acquisition by crops, and aid in the control of rhizosphere phytopathogens such as take-all fungal species, Rhizoctonia fungi and Fusarium wilt fungi [6,71,128-131]. It should be noted, however, that Mn-reducing rhizobacterial strains were primarily tested at soil $\mathrm{pH}<7.5[6,128,129,131]$, and few studies tested their effectiveness under alkaline conditions [132]. Therefore, further testing should focus on assessing the efficacy of rhizobacteria for improving Mn acquisition in alkaline soils, as well as the use of Mn-mobilizing AMF. Nonetheless, biofertilizers comprising Mn-reducing rhizobacteria are highly promising for combatting Mn deficiency in food crops. 


\subsection{Mn in Natural Ecosystems}

The utilization of Mn by fungi and bacteria in forest ecosystems provides some useful insights into the potential issues surrounding the use of microbes for crop biofortification [133-136]. Manganese plays a key role in litter decomposition by fungi, which typically use Mn for two key functions: as a structural component for lignin-degrading enzymes, such as Mn-peroxidase, and as an electron receiver/donator during the decomposition process [133,137]. Initially, fungi acquire either free Mn(II) from easily-degradable fractions of leaf litter or source Mn from the surrounding soil to synthesize enzymes, but if Mn concentrations are insufficient, the fungi compete with plants to acquire Mn [133]. Furthermore, during the later stages of litter degradation, $\mathrm{Mn}$ is cycled enzymatically between readily available $\mathrm{Mn}$ (II) and stabilized Mn(III) to oxidize, and thus degrade, lignin [134-137]. The effect that this redox cycling has on the Mn availability for plants is unclear, but since readily available $\mathrm{Mn}(\mathrm{II})$ is thought to be the predominant form of $\mathrm{Mn}$ in fresh leaf litter, its (albeit temporary) conversion to unavailable $\mathrm{Mn}$ (III) could limit Mn availability to plants [137]. Finally, once leaf litter degradation is complete, Mn accumulates in the form of $\mathrm{Mn}$ (III), which, under aerobic conditions, is oxidized to Mn(IV), further limiting its availability to plants [136,137]. Although research into Mn use by AMF in natural ecosystems is limited, there are likely to be some similarities with Mn use by fungal decomposers [138]. Overall, if AMF Mn cycling in agroecosystems is similar to the fungal cycling of Mn during litter decomposition, it might explain why the application of AMF as biofertilizers can reduce Mn availability to food crops [129].

It was recently discovered that certain strains of bacteria in soils are also capable of oxidizing Mn(II) to yield energy and to protect themselves from harsh environmental conditions via the formation of $\mathrm{Mn}(\mathrm{III} / \mathrm{IV})$ oxide casings [122,137]. However, most research into Mn-reducing strains of rhizobacteria was conducted in agroecosystems [128,129,132]. Therefore, bioprospecting in the soils of semi-natural ecosystems could yield more Mnreducing rhizobacteria suitable for application as biofertilizers.

\section{Cobalt (Co)}

Cobalt (Co) is considered essential for livestock and humans $[9,25,139]$, and although Co is not essential to plants, it is widely regarded as beneficial [140]. In plants, Co is involved in multiple processes, including stem growth, leaf expansion, and bud development [140]. Cobalt is also required for the activation of several enzymes, including those involved in $\mathrm{N}$-fixation in legumes, and is thus particularly beneficial to leguminous crops $[9,139,141-143]$. Importantly, bacteria and archaea are the only organisms capable of utilizing Co to produce cobalamin, also known as vitamin B12, a vital nutrient for mammals, which causes pernicious anaemia in humans suffering from its deficiency $[9,144,145]$. The primary reason for poor vitamin B12 production in leguminous crops is the deficiency of Co in the soil [146].

Cobalt availability is not primarily dictated by soil $\mathrm{pH}[25,139]$. Although increasing soil $\mathrm{pH}$ can reduce Co availability, other soil factors, such as Fe or Mn hydrous oxide abundance, SOM content, soil texture, Mn concentrations, and microbial activity, can equally affect Co availability $[25,139,147,148]$. Since Co is not essential for crop growth, and microbial requirements for this micronutrient are low, Co availability in soils is usually sufficient, and Co deficiency is rarely recorded outside the livestock sector $[25,139,149]$. However, it is important to note that soil contamination from roadside emissions, industrial processes, and sludge application (as an arable management practice) can all result in soil Co concentrations reaching toxic, and eventually biocidal, levels $[25,150]$. Therefore, the careful management of $\mathrm{Co}$ in arable soils is required to ensure microbial and crop plant uptake of these micronutrients is sufficient without becoming excessive, a function that could be fulfilled by biofertilizers. 


\section{Microbial Management of Co in Arable Soils}

To date, there is no research into biofertilizers for managing Co availability in arable soils, even though there are clear links between Co availability and microbial activity. Microbes are thought to induce Co mobilization indirectly by altering soil $\mathrm{pH}$ and reducing $\mathrm{Fe} / \mathrm{Mn}$ hydrous oxides via redox reactions, which inadvertently released precipitated Co $[139,151]$. Depending on whether Co availability is limiting or approaching toxic levels, microbes can directly mobilize or immobilize Co to facilitate or reduce its uptake by organisms regardless of $\mathrm{pH}$, but the mechanisms that microbes employ to achieve this are still unclear [147-149,151]. The quality of SOM could also affect the microbial mobilization of Co because readily available carbon sources can increase microbial activity, and thus Co mobilization, whereas more complex organic compounds have the opposite effect $[148,151]$. Consequently, the application of appropriate organic fertilizers could both enhance Co availability when it becomes limiting and reduce Co mobilization when Co toxicity inhibits microbial activity or crop growth. Finally, there is also some evidence to suggest that crop plants can alter the composition of the rhizosphere community to promote taxa that express genes for Co resistance, which could mitigate Co toxicity [152]. The strong evidence for the microbial control of Co in soils suggests that novel biofertilizers could prove highly effective for managing Co availability, especially if interactions between crop type and biofertilizers are taken into account.

\section{Copper $(\mathrm{Cu})$}

Copper holds a unique role in arable agriculture because, unlike other micronutrients, it is applied both to correct deficiency and as a pesticide [25]. The use of $\mathrm{Cu}$ as a pesticide is one of the causes of widespread soil contamination with $\mathrm{Cu}[25,153,154]$, but here we focus on $\mathrm{Cu}$ deficiency and the role of biofertilizers for maintaining favourable soil $\mathrm{Cu}$ availability.

Copper is essential for numerous crucial biological processes. Copper deficiency is the leading nutritional deficiency in agricultural animals globally, and recent research links $\mathrm{Cu}$ deficiency in humans to ischemic heart disease, osteoporosis, and Alzheimer's disease [155]. In plants, $\mathrm{Cu}$ plays a role in reproduction, photosynthesis, and disease resistance, and $\mathrm{Cu}$ deficiency causes stunted crop growth, yields reductions of up to $20 \%$, and reduces grain or fruit quality $[9,25]$. Crop deficiency in $\mathrm{Cu}$ can occur in soils with low $\mathrm{Cu}$ concentrations or low availability $[9,25,156]$. The low availability of $\mathrm{Cu}$ is often a result of leaching, but also occurs at neutral or alkaline $\mathrm{pH}$ levels and in soils with a high SOM content $[9,25,154,156]$. The biotic complexation of $\mathrm{Cu}$ with SOM and the abiotic adsorption of $\mathrm{Cu}$ onto SOM, (oxy-)hydroxides, clay fractions, and carbonates have the greatest impact on $\mathrm{Cu}$ availability because complexation and adsorption reduce the overall Cu solubility $[9,25,154]$. Approximately $20-40 \%$ of arable soils have a low $\mathrm{Cu}$ availability, which can be exacerbated by cultivating crops that are sensitive to Cu deficiency (e.g., cereals, vegetables, citrus trees), liming, the application of macronutrient fertilizers, and the increased availability of other micronutrients (e.g., Mn, Zn, Fe) [9,25,156].

\section{Solutions for Cu Deficiency}

A prevalent solution to $\mathrm{Cu}$ deficiency in arable soils is the application of $\mathrm{Cu}$ fertilizers or pesticides, repeated as and when they are needed [9]. However, since this approach is partly to blame for widespread $\mathrm{Cu}$ accumulation and the subsequent toxicity in arable soils, agronomists are exploring more sustainable alternatives. For example, nanoparticle fertilizers and pesticides release $\mathrm{Cu}$ into soils at a slow but continuous rate, requiring fewer applications and potentially reducing environmental impacts [157,158]. However, environmental conditions and arable management practices can affect the efficacy of $\mathrm{Cu}$ nanoparticles to the point where detrimental impacts on soil microbial communities are observed [158,159]. By contrast, there is little research into biofertilizers to address $\mathrm{Cu}$ deficiencies in agricultural crops. Studies addressing the microbial biofortification of multiple micronutrients identified numerous taxa capable of increasing $\mathrm{Cu}$ availability and biofortifying crop plants with $\mathrm{Cu}[20,127,131,160]$. Since many soil microbes require $\mathrm{Cu}$ 
as an enzyme cofactor, it is plausible that such species would be efficient $\mathrm{Cu}$ mobilizers, although more research into their underlying mechanisms is required $[79,161]$. Overall, biofertilizers could provide a sustainable method for biofortifying arable food crops with $\mathrm{Cu}$, but their development is currently limited by a paucity of information on microbial $\mathrm{Cu}$ mobilization.

\section{Conclusions}

Numerous environmental factors and intensive agricultural practices can contribute to low micronutrient availability in arable soils, but biofertilizers offer an effective and sustainable way of fortifying crops with micronutrients to improve growth and yield, as well as alleviating hidden hunger in the global human population (Figure 2). Inorganic fertilizers can be costly, unsustainable, and often ineffective, but microorganisms capable of increasing micronutrient acquisition by plants can be used to produce biofertilizers and fortify food crops. By synthesizing the literature, we drew three key conclusions to guide future research and the refinement of biofertilizers (Figure 2):

\section{Addressing Micronutrient Deficiency in Food Production}

\begin{tabular}{|c|c|c|}
\hline $\begin{array}{l}\text { Insufficient Availability } \\
\text { - Unfavourable soil conditions } \\
\text { - Excessive N/P/K application } \\
\text { - Agricultural management } \\
\text { practices } \\
\text { Common cause of all micro-nutrient } \\
\text { deficiencies }\end{array}$ & $\begin{array}{l}\text { Reduced Acquisition } \\
\text { - Fertilizers \& pesticides } \\
\text { interfering with absorption } \\
\text { - High nutrient demand or poor } \\
\text { acquisition strategies of crops } \\
\text { Common cause of } \mathrm{Fe}, \mathrm{Zn}, \mathrm{Mn} \text { and } \mathrm{Cu} \\
\text { deficiencies }\end{array}$ & $\begin{array}{l}\text { Limited Soil Content } \\
\text { - Low content in parent materials } \\
\text { - Input-output imbalance } \\
\text { - Agricultural management } \\
\text { practices } \\
\text { Can contribute to } \mathrm{Zn}, \mathrm{B}, \text { Mo and Mn } \\
\text { deficiencies }\end{array}$ \\
\hline \multicolumn{3}{|c|}{ Application of Microbial Biofertilizers } \\
\hline $\begin{array}{l}\quad \text { Increasing Availability } \\
\text { - Production of siderophores } \\
\text { - Rhizosphere acidification } \\
\text { - Microbial redox cycling }\end{array}$ & $\begin{array}{l}\text { Increasing Acquisition } \\
\text { - Production of siderophores } \\
\text { - Promoting plant root growth } \\
\text { - Forming symbiotic relationships } \\
\text { with crop plants }\end{array}$ & $\begin{array}{l}\text { Co-application with Fertilizers } \\
\text { - Co-application with conventional } \\
\text { fertilizers improves nutrient uptake \& } \\
\text { soil conditions whilst reducing the } \\
\text { amount of fertilizer required }\end{array}$ \\
\hline \multicolumn{3}{|c|}{ Lessons in Biofertilizers from Natural Ecosystems } \\
\hline $\begin{array}{l}\text { 1. Efficacy of biofertilizers will diffe } \\
\text { 2. Co-application of biofertilizers w } \\
\text { 3. Bioprospecting in natural ecosys } \\
\text { and withstanding harsh environ }\end{array}$ & $\begin{array}{l}\text { ng microbial functional groups depe } \\
\text { janic matter could be effective in tre } \\
\text { is a potential source of microbial tax } \\
\text { I conditions in the field }\end{array}$ & $\begin{array}{l}\text { ling on the micronutrient in question } \\
\text { ing some micronutrient deficiencies } \\
\text { capable of mobilizing micronutrients }\end{array}$ \\
\hline
\end{tabular}

Figure 2. Conceptual diagram showing the main causes of micronutrient limitation, strategies for alleviating micronutrient deficiencies using microbial biofertilizers, and research considerations for future research into biofertilizers, based on observations from natural ecosystems.

(1) Microbial functional groups suitable for use as biofertilizers will differ depending on the micronutrient in question, and biotic interactions could undermine their effectiveness. Research to identify microorganisms for developing new micronutrient biofertilizers should not only characterize the mechanisms microbes employed to mobilize and acquire micronutrients, but also assess potential interactions among different microbial functional groups and ascertain the potential for plant-microbial nutrient competition.

(2) The co-application of biofertilizers with inorganic fertilizers proves effective for treating deficiencies of $\mathrm{Zn}, \mathrm{B}$, and Mo, and reduces the amount of inorganic fertilizers needed. Substituting conventional inorganic fertilizers with nano-fertilizers is a growing area of interest, and research into their co-application with biofertilizers could reduce the associated risks of toxicity. Although the co-application of biofertilizers with organic fertilizers is under-researched, work on microbial interactions with easily degradable $\mathrm{SOM}$ in natural ecosystems suggests that the co-application of biofertilizers and organic fertilizers could boost microbial activity and micronutrient availability.

(3) Finally, bioprospecting in natural ecosystems is a potential source of novel microbial taxa that are both capable of mobilizing numerous micronutrients and withstanding 
harsh environmental conditions. Biofertilizers, including such organisms, could mitigate the impacts of climate changes, as well as the negative impacts of conventional arable management practices on soil conditions, which can reduce microbial diversity and abundance. Therefore, the bioprospecting for microbial taxa suitable for reproduction and application as biofertilizers should focus on selecting species that are both highly effective and tolerant of unfavourable environmental conditions.

\begin{abstract}
Author Contributions: S.M.D.-T., E.J.S. conceived the study and wrote the text; S.M.D.-T. performed the literature review, led the writing, and created the diagrams. Both authors contributed to the interpretations and conclusions. All authors have read and agreed to the published version of the manuscript.
\end{abstract}

Funding: This research received no external funding.

Conflicts of Interest: The authors declare no conflict of interest.

\title{
References
}

1. Watson, C.A.; Oborn, I.; Edwards, A.C.; Dahlin, A.S.; Eriksson, J.; Lindstrom, B.E.M.; Linse, L.; Owens, K.; Topp, C.F.E.; Walker, R.L. Using Soil and Plant Properties and Farm Management Practices to Improve the Micronutrient Composition of Food and Feed. J. Geochem. Explor. 2012, 121, 15-24. [CrossRef]

2. Carvalho, S.M.P.; Vasconcelos, M.W. Producing More with Less: Strategies and Novel Technologies for Plant-Based Food Biofortification. Food Res. Int. 2013, 54, 961-971. [CrossRef]

3. Ku, Y.S.; Rehman, H.M.; Lam, O.M. Possible Roles of Rhizospheric and Endophytic Microbes to Provide a Safe and Affordable Means of Crop Biofortification. Agronomy 2019, 9, 764. [CrossRef]

4. Gomiero, T. Soil Degradation, Land Scarcity and Food Security: Reviewing a Complex Challenge. Sustainability 2016, 8, 281. [CrossRef]

5. Power, A.G. Ecosystem Services and Agriculture: Trade-offs and Synergies. Philos. Trans. R. Soc. B 2010, 365, 2959-2971. [CrossRef]

6. Scagliola, M.; Valentinuzzi, F.; Mimmo, T.; Cesco, S.; Crecchio, C.; Pii, Y. Bioinoculants as Promising Complement of Chemical Fertilizers for a More Sustainable Agricultural Practice. Front. Sustain. Food Syst. 2021, 4, 305. [CrossRef]

7. Brady, N. The Nature and Properties of Soils, 8th ed.; Macmillan Publishing Co.: New York, NY, USA, 1974.

8. Fageria, N.K.; Baligar, V.C.; Clark, R.B. Micronutrients in Crop Production. Adv. Agron. 2002, 77, $185-268$.

9. Alloway, B.J. Micronutrient Deficiencies in Global Crop Production; Springer Science \& Business Media B.V.: Berlin, Germany, 2008.

10. He, Z.L.; Yang, X.E.; Stoffella, P.J. Trace Elements in Agroecosystems and Impacts on the Environment. J. Trace Elem. Med. Biol. 2005, 19, 125-140. [CrossRef]

11. Lowe, N.M. The global challenge of hidden hunger: Perspectives from the field. Proc. Nutr. Soc. 2021, 80, 283-289. [CrossRef]

12. World Health Organisation (WHO) Guidelines on Food Fortification with Micronutrients. 2006. Available online: https: //www.who.int/publications/i/item/9241594012 (accessed on 1 July 2021).

13. World Health Organisation (WHO) Vitamin and Mineral Nutrition Information System (VMNIS). 2021. Available online: https: //www.who.int/teams/nutrition-and-food-safety/databases/vitamin-and-mineral-nutrition-information-system (accessed on 1 July 2021)

14. Ritchie, H.; Roser, M. Our World in Data: Micronutrient Deficiency. 2017. Available online: https://ourworldindata.org/ micronutrient-deficiency (accessed on 1 July 2021).

15. Fisher, G.E.J. Micronutrients and Animal Nutrition and the Link between the Application of Micronutrients to Crops and Animal Health. Turk. J. Agric. For. 2008, 32, 221-233.

16. White, P.J.; Broadley, M.R. Biofortification of Crops with Seven Mineral Elements Often Lacking in Human Diets-Iron, Zinc, Copper, Calcium, Magnesium, Selenium and Iodine. New Phytol. 2009, 182, 49-84. [CrossRef]

17. World Health Organisation (WHO) Biofortification of Staple Crops. 2019. Available online: https://www.who.int/elena/titles/ biofortification/en/ (accessed on 1 July 2021).

18. Abhilash, P.C.; Dubey, R.K.; Tripathi, V.; Gupta, V.K.; Singh, H.B. Plant Growth-Promoting Microorganisms for Environmental Sustainability. Trends Biotechnol. 2016, 34, 847-850. [CrossRef]

19. Singh, D.; Prasanna, R. Potential of Microbes in the Biofortification of Zn and Fe in Dietary Food Grains. A Review. Agron. Sustain. Dev. 2020, 40, 15. [CrossRef]

20. Behera, B.; Das, T.K.; Raj, R.; Ghosh, S.; Raza, B.; Sen, S. Microbial Consortia for Sustaining Productivity of Non-Legume Crops: Prospects and Challenges. Agric. Res. 2021, 10, 1-14. [CrossRef]

21. Mitter, E.K.; Tosi, M.; Obregon, D.; Dunfield, K.E.; Germida, J.J. Rethinking Crop Nutrition in Times of Modern Microbiology: Innovative Biofertilizer Technologies. Front. Sustain. Food Syst. 2021, 5, 29. [CrossRef]

22. Pii, Y.; Mimmo, T.; Tomasi, N.; Terzano, R.; Cesco, S.; Crecchio, C. Microbial Interactions in the Rhizosphere: Beneficial Influences of Plant Growth-Promoting Rhizobacteria on Nutrient Acquisition Process. A Review. Biol. Fertil. Soil. 2015, 51, 403-415. [CrossRef]

23. Verma, S.; Kuila, A. Bioremediation of Heavy Metals by Microbial Process. Environ. Technol. Innov. 2019, 14, 100369. [CrossRef]

24. Yadav, K.K.; Gupta, N.; Kumar, V.; Singh, J.K. Bioremediation of Heavy Metals from Contaminated Sites Using Potential Species: A Review. Indian J. Environ. Prot. 2017, 37, 65-84. 
25. Kabata-Pendias, A. Trace Elements in Soils and Plants; Taylor \& Francis Group: Baton Rouge, LA, USA, 2010.

26. Siqueira Freitas, D.; Wurr, R.; Reis dos Rodrigues, A.; De Barros Reis, F.; Soares de Carvalho, T.; Schulze, J.; Carbone Carneiro, M.A.; Guimaraes Guilherme, L.R. Hidden Nickel Deficiency? Nickel Fertilization Via Soil Improves Nitrogen Metabolism and Grain Yield in Soybean Genotypes. Front. Plant Sci. 2018, 9, 614. [CrossRef]

27. Barman, M.; Datta, S.P.; Rattan, R.K.; Meena, M.C. Critical Limits of Deficiency of Nickel in Intensively Cultivated Alluvial Soils. J. Soil Sci. Plant Nutr. 2019, 20, 284-292. [CrossRef]

28. Sayer, E.J. The Anatomy of an Excellent Review Paper. Funct. Ecol. 2018, 32, 2278-2281. [CrossRef]

29. Lemanceau, P.; Bauer, P.; Kraemer, S.; Briat, J.-F. Iron Dynamics in the Rhizosphere as a Case Study for Analysing Interactions between Soils, Plants and Microbes. Plant Soil 2009, 321, 513-535. [CrossRef]

30. Whitehead, D.C. Nutrient Elements in Grassland: Soil-Plant-Animal Relationships; CABI Publishing: Wallingford, UK, 2000.

31. Meena, V.S.; Meena, S.K.; Verma, J.P.; Kumar, A.; Aeron, A.; Mishra, P.K.; Bisht, J.K.; Pattanayak, A.; Naveed, M.; Dotaniya, M.L. Plant Beneficial Rhizospheric Microorganism (PBRM) Strategies to Improve Nutrients Use Efficiency: A Review. Ecol. Eng. 2017, 107, 8-32. [CrossRef]

32. Buni, A. Effects of Liming Acidic Soils on Improving Soil Properties and Yield of Haricot Bean. J. Environ. Anal. Toxicol. 2014, 4, 1-4.

33. Mimmo, T.; Del Buono, D.; Terzano, R.; Tomasi, N.; Vigani, G.; Crecchio, C.; Pinton, R.; Zocchi, G.; Cesco, S. Rhizospheric Organic Compounds in the Soil-Microorganism-Plant System: Their Role in Iron Availability. Eur. J. Soil Sci. 2014, 65, 629-642. [CrossRef]

34. Calabrese, S.; Barcellos, D.; Thompson, A.; Porporato, A. Theoretical Constrains on Fe Reduction Rates in Upland Soils as Function of Hydroclimatic Conditions. J. Geophys. Res. Biogeosciences 2020, 125, e2020JG005894. [CrossRef]

35. Abbasi, M.K.; Zafar, M.; Sultan, T. Changes in Soil Properties and Microbial Indices across Various Management Sites in the Mountain Environments of Azad Jammu and Kashmir. Commun. Soil Sci. Plant Anal. 2010, 41, 768-782. [CrossRef]

36. Deiss, L.; Kleina, G.B.; Moraes, A.; Franzluebbers, A.J.; Motta, A.C.V.; Dieckow, J.; Sandini, I.E.; Anghinoni, I.; Carvalho, P.C.F. Soil Chemical Properties Under No-Tillage as Affected by Agricultural Trophic Complexity. Eur. J. Soil Sci. 2019, 71, 1090-1105. [CrossRef]

37. Bhople, B.S.; Sharma, S. Seasonal Variation of Rhizospheric Soil Properties under Different Land Use Systems at Lower Shivalik Foothills of Punjab, India. Agrofor. Syst. 2020, 94, 1959-1976.

38. Schiere, J.B.; Ibrahim, M.N.M.; Van Keulen, H. The Role of Livestock for Sustainability in Mixed Farming: Criteria and Scenario Studies under Varying Resource Allocation. Agric. Ecosyst. Environ. 2002, 2, 139-153. [CrossRef]

39. Sharma, S.; Dhaliwal, S.S. Effects of Sewage Sludge and Rice Straw Compost on Yield, Micronutrient Availability and Soil Quality under Rice-Wheat System. Commun. Soil Sci. Plant Anal. 2019, 50, 1943-1954. [CrossRef]

40. Eker, S.; Ozturk, L.; Yazici, A.; Erenoglu, B.; Romheld, V.; Cakmak, I. Foliar-Applied Glyphosate Substantially Reduced Uptake and Transport of Iron and Manganese in Sunflower (Helianthus annus L.) Plants. J. Agric. Food Chem. 2006, 54, 10019-10025. [CrossRef] [PubMed]

41. Osborne, L.D.; Robson, A.D.; Bowran, D.G. The Impact of Chlorsulfuron and Diclofop-Methyl on Nutrient Uptake by Wheat Aust. J. Agric. Res. 1993, 44, 1757-1766. [CrossRef]

42. Kraemer, S.M.; Crowley, D.E.; Kretzschmar, R. Geochemical Aspects of Phytosiderophore-Promoted Iron Acquisition by Plants. Adv. Agron. 2006, 91, 1-46.

43. Ferreira, M.J.; Silva, H.; Cunha, A. Siderophore-Producing Rhizobacteria as a Promising Tool for Empowering Plants to Cope with Iron Limitation in Saline Soils: A Review. Pedosphere 2019, 29, 409-420. [CrossRef]

44. Curie, C.; Briat, J.F. Iron Transport and Signalling in Plants. Annu. Rev. Plant Biol. 2003, 54, 183-206. [CrossRef]

45. Marschner, P.; Crowley, D.; Rengel, Z. Rhizosphere Interactions between Microorganisms and Plants Governs Iron and Phosphorus Acquisition along the Root Axis-Model and Research Methods. Soil Biol. Biochem. 2011, 43, 883-894. [CrossRef]

46. Schroder, I.; Johnson, E.; De Vries, S. Microbial Ferric Iron Reductases. FEMS Microbiol. Rev. 2003, 27, 427-447. [CrossRef]

47. Colombo, C.; Palumbo, G.; He, J.-Z.; Pinton, R.; Cesco, S. Review on Iron Availability in Soil: Interaction of Fe Minerals, Plants, and Microbes. J. Soils Sedim. 2014, 14, 538-548. [CrossRef]

48. Roriz, M.; Carvalho, S.M.P.; Castro, P.M.L.; Vasconcelos, M.W. Legume Biofortification and the Role of Plant Growth-Promoting Bacteria in a Sustainable Agricultural Era. Agronomy 2020, 10, 435. [CrossRef]

49. Saha, M.; Sarkar, S.; Sarkar, B.; Sharma, B.K.; Bhattacharjee, S.; Tribedi, P. Microbial Siderophores and Their Potential Applications: A Review. Environ. Sci. Pollut. Res. 2016, 23, 3984-3999. [CrossRef]

50. Vaid, S.K.; Kumar, A.; Sharma, A.; Srivastava, P.C.; Shukla, A.K. Role of Some Plant Growth Promotory Bacteria in Enhanced Fe Uptake of Wheat. Commun. Soil Sci. Plant Anal. 2017, 48, 756-768. [CrossRef]

51. Yehuda, Z.; Shenker, M.; Romheld, V.; Marschner, H.; Hadar, Y.; Chen, Y. The Role of Ligand Exchange in the Uptake of Iron from Microbial Siderophores by Gramineous Plants. Plant Physiol. 1996, 112, 1273-1280. [CrossRef]

52. Ali, S.; Hayat, R.; Begum, F.; Bohannan, B.J.M.; Inebert, L.; Meyer, K. Variation in Soil Physical, Chemical and Microbial Parameters Under Different Land Uses in Bagrot Valley, Gilgit, Pakistan. J. Chem. Soc. Pak. 2017, 39, 97-107.

53. Bhattacharyya, A.; Campbell, A.N.; Tfaily, M.M.; Lin, Y.; Kukkadapu, R.K.; Silver, W.L.; Nico, P.S.; Pett-Ridge, J. Redox Fluctuations Control the Coupled Cycling of Iron and Carbon in Tropical Forest Soils. Environ. Sci. Technol. 2018, 52, 14129-14139. [CrossRef]

54. Chacon, N.; Silver, W.L.; Dubinsky, E.A.; Cusack, D.F. Iron Reduction and Soil Phosphorus Solubilization in Humid Tropical Forest Soils: The Roles of Labile Carbon Pools and an Electron Shuttle Compound. Biogeochemistry 2006, 78, 67-84. [CrossRef]

55. Dubinsky, E.A.; Silver, W.L.; Firestone, M.K. Tropical Forest Soil Microbial Communities Couple Iron and Carbon Biogeochemistry. Ecology 2010, 91, 2604-2612. [CrossRef] 
56. Barcellos, D.; O'Connell, C.S.; Silver, W.; Meile, C.; Thompson, A. Hot Spots and Hot Moments of Soil Moisture explain Fluctuations in Iron and Carbon Cycling in a Humid Tropical Forest Soil. Soil Syst. 2018, 2, 59. [CrossRef]

57. Adhikari, P.; Pandey, A. Bioprospecting Plant Growth Promoting Endophytic Bacteria Isolated from Himalayan Yew (Taxus wallichiana Zucc.). Microbiol. Res. 2020, 239, 126536. [CrossRef]

58. Dastager, S.G.; Deepa, C.K.; Pandey, A. Plant Growth Promoting Potential of Pontibacter niistensis in Cowpea (Vigna unguiculata (L.) Walp.). Appl. Soil Ecol. 2011, 49, 250-255. [CrossRef]

59. Balcazar, W.; Rondon, J.; Rengifo, M.; Ball, M.M.; Melfo, A.; Gomez, W.; Yarzabal, L.A. Bioprospecting Glacial Ice for Plant growth promoting Bacteria. Microbiol. Res. 2015, 177, 1-7. [CrossRef]

60. Yadav, A.N.; Sachan, S.G.; Verma, P.; Saxena, A.K. Bioprospecting of Plant Growth Promoting Psychrotrophic Bacilli from the Cold Desert of North Western Indian Himalayas. Indian J. Exp. Biol. 2016, 52, 142-150.

61. Boiteau, R.M.; Shaw, J.B.; Pasa-Tolic, L.; Koppenaal, D.W.; Jansson, J.K. Micronutrient Metal Speciation is Controlled by Competitive Organic Chelation in Grassland Soils. Soil Biol. Biochem. 2018, 120, 283-291. [CrossRef]

62. Kusel, K.; Wagner, C.; Trinkwalter, T.; Gossner, A.S.; Baumler, R.; Drake, H.L. Microbial Reduction of Fe(III) and Turnover of Acetate in Hawaiian Soils. FEMS Microbiol. Ecol. 2002, 40, 73-81. [CrossRef]

63. Singh, B.; Natesan, S.K.A.; Singh, B.K.; Usha, K. Improving Zinc Efficiency of Cereals under Zinc Deficiency. Curr. Sci. 2005, 88, 36-44.

64. Ullah, A.; Farooq, M.; Rehman, A.; Hussain, M.; Siddique, K.H.M. Zinc Nutrition in Chickpea (Cicer arietinum): A Review. Crop Pasture Sci. 2020, 71, 199-218. [CrossRef]

65. Nepomuceno, R.A.; Brown, C.B.; Gargarino, A.M.P.; Pedro, M.S.; Brown, M.B. Growth Enhancement of Rice (Oryza sativa L.) by Zinc-Solubilising Bacteria Isolated from Vesicular-Arbuscular Mycorrhizal Root Inoculant (VAMRI). Philipp. J. Crop Sci. 2020, 45, 34-40.

66. Imran, M.; Arshad, M.; Khalid, A.; Kanwal, S.; Crowley, D.E. Perspectives of Rhizosphere Microflora for Improving Zn Bioavailability and Acquisition by Higher Plants. Int. J. Agric. Biol. 2014, 16, 653-662.

67. Bala, R.; Kalia, A.; Dhaliwal, S.S. Evaluation of Efficacy of ZnO Nanoparticles as Remedial Zinc Nanofertilizer for Rice. J. Soil Sci. Plant Nutr. 2019, 19, 379-389. [CrossRef]

68. Ramesh, A.; Sharma, S.K.; Sharma, M.P.; Yadav, N.; Joshi, O.P. Inoculation of Zinc Solubilising Bacillus araybhattai Strains for Improved Growth, Mobilization and Biofortification of Zinc in Soybean and Wheat Cultivated in Vertisols of Central India. Appl. Soil Ecol. 2014, 73, 87-96. [CrossRef]

69. Strachel, R.; Zaborowska, M.; Wyszkowska, J. Deliberations on Zinc-A Trace Mineral of a Toxic Element? J. Elem. 2016, 21, 625-639.

70. Yang, X.-W.; Tian, X.-H.; Lu, X.-C.; Cao, Y.-X.; Chen, Z.-H. Impacts of Phosphorus and Zinc Levels on Phosphorus and Zinc Nutrition and phytic Acid Concentration in Wheat (Triticum aestivum L.). Sci. Food Agric. 2011, 91, 2322-2328. [CrossRef] [PubMed]

71. Rengel, Z. Availability of Mn, Zn and Fe in the Rhizosphere. J. Soil Sci. Plant Nutr. 2015, 15, 397-409. [CrossRef]

72. Dubey, A.N.; Chattopadhyaya, N.; Mandal, N. Variation in Soil Microbial Population and Soil Enzymatic Activities Under Zincated Nanoclay Polymer Composites (ZNCPCs), Nano-ZnO and Zn Solubilizers in Rice Rhizosphere. Agric. Res. 2021, 10, 21-31. [CrossRef]

73. Ash, M.; Yadav, J.; Yadav, J.S. Yield Attributes of Rice (Oryza Sativa) as Affected by Integrated Use of Zinc Oxide and Zinc Solubilizers. Indian J. Agric. Sci. 2020, 90, 2180-2184.

74. Subramanian, K.S.; Tenshia, V.; Jayalakshmi, K.; Ramachandran, V. Biochemical Changes and Zinc Fractions in Arbuscular Mycorrhizal Fungi (Glomus intraradices) Inoculated and Uninoculated Soils under Differential Zinc Fertilization. Appl. Soil Ecol. 2009, 43, 32-39. [CrossRef]

75. Suganya, A.; Saravanan, A.; Baskar, M.; Pandiyarajan, P.; Kavimani, R. Agronomic Biofortification of Maize (Zea mays L.) with Zinc by Using of Graded Levels of Zinc in Combination with Zinc Solubilising Bacteria and Arbuscular Mycorrhizal Fungi. J. Plant Nutr. 2020, 44, 988-994. [CrossRef]

76. Vaid, S.K.; Srivastava, P.C.; Sharma, A.; Rawat, D.; Mathpal, B.; Shankhadhar, S.C.; Shukla, A.K. Residual Effect of Zinc Applied to Rice on Zinc Nutrition of Succeeding Wheat Crop Inoculated with Zinc Solubilizing Microbial Consortium. Isr. J. Plant Sci. 2019, 66, 227-237. [CrossRef]

77. Liu, Y.M.; Cao, W.Q.; Chen, X.X.; Yu, B.G.; Lang, M.; Chen, X.P.; Zou, C.Q. The Responses of Soil Enzyme Activities, Microbial Biomass and Microbial Community Structure to Nine Years of Varied Zinc Application Rates. Sci. Total Environ. 2020, 737, 140245. [CrossRef]

78. Qin, N.; Sun, M.T.; Zhu, L.X.; Ge, C.M.; Wang, J. Residual Effects of Soil Zn Fertilization on Soil Characteristics, Yield and Quality of Platycodon grandiflorum. Soil Sci. Plant Nutr. 2020, 66, 344-351.

79. Asadishad, B.; Chahal, S.; Akbari, A.; Cianciarelli, V.; Azodi, M.; Ghoshal, S.; Tufenkji, N. Amendment of Agricultural Soil with Metal Nanoparticles: Effects of Soil Enzyme Activity and Microbial Community Composition. Environ. Sci. Technol. 2018, 52, 1908-1918. [CrossRef]

80. Garcia-Gomez, C.; Fernandez, M.D.; Garcia, S.; Obrador, A.F.; Leton, M.; Babin, M. Soil pH Effects the Toxicity of Zinc Oxide Nanoparticles to the Soil Microbial Community. Environ. Sci. Pollut. Res. 2018, 25, 28140-28152. [CrossRef]

81. Liu, Y.; Li, Y.; Pan, B.; Zhang, H.; Steinberg, C.E.W.; Qiu, H.; Vijver, M.G.; Peijnenburg, W.J.G.M. Application of Low Dosage of Copper Oxide and Zinc Oxide Nanoparticles Boosts Bacterial and Fungal Communities in Soil. Sci. Total Environ. 2021, 757, 143807. [CrossRef] 
82. Xu, J.B.; Luo, X.S.; Wang, Y.L.; Feng, Y.Z. Evaluation of Zinc Oxide Nanoparticles on Lettuce (Lactuca sativa L) Growth and Soil Bacterial Community. Environ. Sci. Pollut. Res. 2018, 25, 6026-6035. [CrossRef]

83. Alloway, B.L. Zinc in Soils and Crop Nutrition, 2nd ed.; IZA: Brussels, Belgium; IFA: Paris, France, 2008.

84. Boardman, R.; McGuire, D.O. The Role of Zinc in Forestry, I. Zinc in Forest Environments, Ecosystems and Tree Nutrition. For. Ecol. Manag. 1990, 37, 167-205. [CrossRef]

85. Macdonald, C.A.; Clark, I.M.; Zhao, F.J.; Hirsch, P.R.; Singh, B.K.; McGrath, S.P. Long-Term Impacts of Zinc and Copper Enriched Sewage Sludge Additions on Bacterial, Archaeal and Fungal Communities in Arable and Grassland Soils. Soil Biol. Biochem. 2011, 43, 932-941. [CrossRef]

86. Zaheer, A.; Malik, A.; Sher, A.; Qaisrani, M.M.; Mehmood, A.; Khan, S.U.; Ashraf, M.; Mirza, Z.; Karim, S.; Rasool, M. Isolation, Characterization, and Effect of Phosphate-Zinc-Solubilising Bacterial Strains on Chickpea (Cicer arietinum L.) Growth. Saudi J. Biol. Sci. 2019, 26, 1061-1067. [CrossRef]

87. Liu, P.; Yang, Y.S.; Xu, G.D.; Fang, Y.H.; Yang, Y.A.; Kalin, R.M. The effect of molybdenum and boron in soil on the growth and photosynthesis of three soybean varieties. Plant Soil Environ. 2005, 51, 197-205. [CrossRef]

88. Gupta, S.C.; Sahu, S. Response of Chickpea to Micronutrients and Biofertilizers in Vertisol. Legume Res. 2012 , 35, $248-251$.

89. Sun, T.; Wang, Y.P.; Wang, Z.Y.; Liu, P.; Xu, G.D. The Effects of Molybdenum and Boron on the Rhizosphere Microorganisms and Soil Enzyme Activities of Soybean. Acta Physiol. Plant. 2013, 35, 763-770. [CrossRef]

90. Mandal, M.; Naik, S.K.; Das, D.K. Effect of Boron and Sulphur Interaction on Some Important Biological Indices in an Inceptisol. J. Plant Nutr. 2018, 41, 197-209.

91. Abreu, I.; Cerda, M.E.; De Nanclares, M.P.; Baena, I.; Lloret, J.; Bonilla, I.; Bolanos, L.; Reguera, M. Boron Deficiency Affects Rhizobia Cell Surface Polysaccharides Important for Suppression of Plant Defence Mechanisms During Legume Recognition and for the Development of Nitrogen-Fixing Symbiosis. Plant Soil 2012, 361, 385-395. [CrossRef]

92. National Institutes of Health Office of Dietary Supplements: Boron. Available online: https://ods.od.nih.gov/factsheets/BoronHealthProfessional/ (accessed on 3 August 2021).

93. Rana, M.S.; Hu, C.X.; Shaaban, M.; Imran, M.; Afzal, J.; Moussa, M.G.; Elyamine, A.M.; Bhantana, P.; Saleem, M.H.; Syaifudin, M.; et al. Soil Phosphorus Transformation Characteristics in Response to Molybdenum Supply in Leguminous Crops. J. Environ. Manag. 2020, 268, 110610. [CrossRef]

94. Rana, M.S.; Sun, X.C.; Imran, M.; Ali, S.; Shaaban, M.; Moussa, M.G.; Khan, Z.; Afzal, J.; Binyamin, R.; Bhantana, P.; et al. Hu CX Molybdenum-Induced Effects on Leaf Ultra-Structure Rhizosphere Phosphorus Transformation in Triticum aestivum, L. Plant Physiol. Biochem. 2020, 153, 20-29. [CrossRef]

95. Ge, X.X.; Vaccaro, B.J.; Thorgersen, M.P.; Poole, F.L.; Majumder, E.L.; Zane, G.M.; De Leon, K.B.; Lancaster, W.A.; Moon, J.W.; Paradis, C.J.; et al. Iron- and Aluminium- Induced Depletion of Molybdenum in Acidic Environments Impedes the Nitrogen Cycle. Environ. Microbiol. 2019, 21, 152-163. [CrossRef]

96. Rajakumari, R.; Oluwafemi, O.S.; Thomas, S.; Kalarikkal, N. Dietary Supplements Containing Vitamins and Minerals: Formulation, Optimization and Evaluation. Powder Technol. 2018, 336, 481-492. [CrossRef]

97. Hua, T.W.; Zhang, R.; Sun, H.W.; Liu, C.G. Alleviation of Boron Toxicity in Plants: Mechanisms and Approaches. Crit. Rev. Environ. Sci. Technol. 2020, 51, 2975-3015. [CrossRef]

98. Adhikari, L.; Missaoui, A.M. Nodulation Response to Molybdenum Supplementation in Alfalfa and its Correlation with Root and Shoot Growth in Low pH Soil. J. Plant Nutr. 2017, 40, 2290-2302. [CrossRef]

99. Kwiatkowski, C.A.; Harasim, E. Chemical Properties of Soil in Four-Field Crop Rotations under Organic and Conventional Farming Systems. Agronomy 2020, 10, 1045. [CrossRef]

100. Nadeem, F.; Farooq, M.; Nawaz, A.; Ahmad, R. Boron Improves Productivity and Profitability of Bread Wheat under Zero and Plough Tillage on Alkaline Calcareous Soil. Field Crops Res. 2019, 239, 1-9. [CrossRef]

101. Vera, A.; Moreno, J.L.; Siles, J.A.; Lopez-Mondejar, R.; Zhou, Y.; Li, Y.; Garcia, C.; Nicolas, E.; Bastida, F. Interactive Impacts of Boron and Organic Amendments in Plant-Soil Microbial Relationships. J. Hazard. Mater. 2021, 408, 124939. [CrossRef]

102. Bilen, S.; Bilen, M.; Bardhan, S. The Effects of Boron Management on Soil Microbial Population and Enzyme Activities. Afr. J. Biotechnol. 2011, 10, 5311-5319.

103. Mahmud, K.; Makaju, S.; Ibrahim, R.; Missaoui, A. Current Progress in Nitrogen Fixing Plants and Microbiome Research. Plants 2020, 9, 97. [CrossRef]

104. Parniske, M. Intracellular Accommodation of Microbes by Plants: A Common Developmental Program for Symbiosis and Disease? Curr. Opin. Plant Biol. 2000, 3, 320-328. [CrossRef]

105. Zehirov, G.; Georgiev, G. Relationships Between Cell Membrane Stability, Exudate Content and Infectivity of Bradyrhizobium japonicum Strain 639 to Boron Staved Soybean Plants. Acta Physiol. Plant 2006, 28, 171-179. [CrossRef]

106. Zhang, Y.; Gladyshev, V.N. Molybdoproteomes and Evolution of Molybdenum Utilisation. J. Mol. Biol. 2008, 379, 881-899. [CrossRef]

107. Kristek, S.; Resic, I.; Jovic, J.; Zmajic, K.; Lenart, L.; Kraljicak, Z.; Beslo, D.; Rasic, S. Effect of Various Rates of Boron on Yield and Quality of High-Grade Sugar Beet Varieties. Lis. Cukrov. A Repar. 2018, 134, 146-150.

108. Vera, A.; Moreno, J.L.; Garcia, C.; Morais, D.; Bastida, F. Boron in Soil: The Impacts on the Biomass, Composition and Activity of the Soil Microbial Community. Sci. Total Environ. 2019, 685, 564-573. [CrossRef]

109. Barron, A.R.; Wurzburger, N.; Bellenger, J.P.; Wright, S.J.; Kraepiel, A.M.L.; Hedin, L.O. Molybdenum Limitation of Asymbiotic Nitrogen Fixation in Tropical Forest Soils. Nat. Geosci. 2009, 2, 42-45. [CrossRef] 
110. Wen, X.; Hu, C.X.; Sun, X.C.; Zhao, X.H.; Tan, Q.L.; Liu, P.J.; Xin, J.; Qin, S.Y.; Wang, P.C. Characterisation of Vegetable Nitrogen Uptake and Soil Nitrogen Transformation in Response to Continuous Molybdenum Application. J. Plant Nutr. Soil Sci. 2018, 181, 516-527. [CrossRef]

111. Franczuk, J.; Rosa, R.; Zaniewicz-Bajkowska, A.; Slonecka, D. Effects of Boron Application and Treatment with Effective Microorganisms on the Growth, Yield and some Quality Attributes of Broccoli. J. Elem. 2019, 24, 1335-1348.

112. Shcherbakova, E.N.; Shcherbakov, A.V.; Andronov, E.E.; Gonchar, L.N.; Kalenskaya, S.M.; Chebotar, V.K. Combined Pre-Seed Treatment with Microbial Inoculants and Mo Nanoparticles Changes Composition of Root Exudates and Rhizosphere Microbiome Structure of Chickpea (Cicer arietinum L.) Plants. Symbiosis 2017, 73, 57-59. [CrossRef]

113. Taran, N.Y.; Gonchar, O.M.; Lopatko, K.G.; Batsmanova, L.M.; Patyka, M.V.; Volkogon, M.V. The Effect of Colloidal Solution of Molybdenum Nanoparticles on the Microbial Composition in Rhizosphere of Cicer arietinum L. Nanoscale Res. Lett. 2014, 9, 289. [CrossRef]

114. Lehto, T.; Smolander, A.; Aphalo, P.J. Decomposition and Element Concentrations of Silver Birch Leaf Litter as Affected by Boron Status of Litter and Soil. Plant Soil 2010, 329, 195-208. [CrossRef]

115. Reed, S.C.; Cleveland, C.C.; Townsend, A.R. Relationships among Phosphorus, Molybdenum and Free-Living Nitrogen Fixation in Tropical Rainforests: Results from Observational and Experimental Analyses. Biogeochemistry 2013, 114, 135-147. [CrossRef]

116. Wichard, T.; Mishra, B.; Myneni, S.C.B.; Bellenger, J.P.; Kraepiel, A.M.L. Storage and Bioavailability of Molybdenum in Soils Increased by Organic Matter Complexation. Nat. Geosci. 2009, 2, 625-629. [CrossRef]

117. Liermann, L.J.; Guynn, R.L.; Anbar, A.; Brantley, S.L. Production of Molybdophore during Metal Targeted Dissolution of Silicates by Soil Bacteria. Chem. Geol. 2005, 220, 285-302. [CrossRef]

118. Zulfiqar, U.; Hussain, S.; Ishfaq, M.; Ali, N.; Ahmad, M.; Ihsan, F.; Sheteiwy, M.S.; Rauf, A.; Hano, C.; El-Esawi, M.A. Manganese Supply Improves Bread Wheat Productivity, Economic Returns and Grain Biofortification Under Conventional and No Tillage Systems. Agriculture 2021, 11, 142. [CrossRef]

119. Mukhopadhyay, M.J.; Sharma, A. Manganese in Cell Metabolism in Higher Plants. Bot. Rev. 1991, 57, 117-149. [CrossRef]

120. World Health Organisation: Regional Office of Europe (WHO) Chapter 6.8: Manganese. 2001. Available online: https://www. euro.who.int/_data/assets/pdf_file/0003/123078/AQG2ndEd_6_8Manganese.pdf (accessed on 11 August 2021).

121. Zulfiqar, U.; Hussain, S.; Ishfaq, M.; Ali, N.; Yasin, M.U.; Ali, M.A. Foliar Manganese Supply Enhances Crop Productivity, Net Benefits, and Grain Manganese Accumulation in Direct-Seeded and Puddled Transplanted Rice. J. Plant Growth Regul. 2021, 40, 1539-1556. [CrossRef]

122. Yang, W.H.; Zhang, Z.; Chen, H.; Liu, J.; Ali, M.; Liu, F.; Li, L. Population Structure of Manganese-Oxidising Bacteria in Stratified Soils and Properties of Manganese Oxide Aggregates Under Manganese-Complex Medium Enrichment. PLoS ONE 2013, 8, e73778.

123. Terzano, R.; Cuccovillo, G.; Gattullo, C.E.; Medici, L.; Tomasi, N.; Pinton, R.; Mimmo, T.; Cesco, S. Combined Effect of Soil Organic Acids and Flavonoids on the Mobilization of Major and Trace Elements from Soil. Biol. Fertil. Soils 2015, 51, 685-695. [CrossRef]

124. Zhang, F.S. Mobilization of Iron and Manganese by Plant-Borne and Synthetic Metal Chelators. Plant Soil 1993, 155, 111-114. [CrossRef]

125. Williams, C.H.; David, D.J. Effects of Pasture Improvement with Subterranean Clover and Superphosphate on the Availability of Trace Metals to Plants. Aust. J. Soil Res. 1976, 14, 85-93. [CrossRef]

126. Bowles, T.M.; Mooshammer, M.; Socolar, Y.; Calderon, F.; Cavigelli, M.A.; Culman, S.W.; Deen, W.; Drury, C.F.; Y Garcia, A.G.; Gaudin, A.C.M.; et al. Long-Term Evidence Shows that Crop-Rotation Diversification Increases Agricultural Resilience to Adverse Growing Conditions in North America. One Earth 2020, 2, 284-293. [CrossRef]

127. Ogut, M.; Er, F. Micronutrient Composition of Field-Grown Dry Bean and Wheat Inoculated with Azospirillum and Trichoderma. J. Plant Nutr. Soil Sci. 2006, 169, 699-703. [CrossRef]

128. Posta, K.; Marschner, H.; Romheld, V. Manganese Reduction in the Rhizosphere of Mycorrhizal and Nonmycorrhizal Maize. Mycorrhiza 1994, 5, 119-124. [CrossRef]

129. Kothari, S.K.; Marschner, H.; Romheld, V. Effect of Vesicular Arbuscular Mycorrhizal Fungus and Rhizosphere Microorganisms on Manganese Reduction in the Rhizosphere and Manganese Concentrations in Maize (Zea-mays L.). New Phytol. 1991, 117, 649-655. [CrossRef]

130. Piromyou, P.; Buranabanyat, B.; Tantasawat, P.; Tittabutr, P.; Boonkerd, N.; Teaumroong, N. Effect of Plant Growth Promoting Rhizobacteria (PGPR) Inoculation on Microbial Community Structure in Rhizosphere of Forage Corn Cultivated in Thailand. Eur. J. Soil Biol. 2011, 47, 44-54. [CrossRef]

131. Rana, A.; Saharan, B.; Nain, L.; Prasanna, R.; Shivay, Y.S. Enhancing Micronutrient Uptake and Yield of Wheat through Bacterial PGPR Consortia. Soil Sci. Plant Nutr. 2012, 58, 573-582. [CrossRef]

132. Marschner, P.; Ascher, J.S.; Graham, R.D. Effect of Manganese-Reducing Rhizosphere Bacteria on the Growth of Gaeumannomyces graminis var. tritici and on Manganese Uptake by Wheat (Triticum aestivum L.). Biol. Fertil. Soil. 1991, 12, 33-38. [CrossRef]

133. Innangi, M.; Schenk, M.K.; D'Alessandro, F.; Pinto, S.; Menta, C.; Papa, S.; Fioretto, A. Field and Microcosms Decomposition Dynamics of European Beech Leaf Litter: Influence of Climate, Plant Material and Soil with Focus on N and Mn. Appl. Soil Ecol. 2015, 93, 88-97. [CrossRef]

134. Jones, M.E.; LaCroix, R.E.; Zeigler, J.; Ying, S.C.; Nico, P.S.; Keiluweit, M. Enzymes, Manganese, or Iron? Drivers of Oxidative Organic Matter Decomposition in Soils. Environ. Sci. Technol. 2020, 54, 14114-14123. [CrossRef] 
135. Sun, T.; Cui, Y.; Berg, B.; Zhang, Q.; Dong, L.; Wu, Z.; Zhang, L. A Test of Manganese Effects on Decomposition in Forest and Cropland Sites. Soil Biol. Biochem. 2019, 129, 178-183. [CrossRef]

136. Whalen, E.D.; Smith, R.G.; Grandy, S.; Frey, S.D. Manganese Limitation as a Mechanism for Reduced Decomposition in Soils under Atmospheric Nitrogen Deposition. Soil Biol. Biochem. 2018, 127, 252-263. [CrossRef]

137. Keiluweit, M.; Nico, P.; Harmon, M.E.; Mao, J.D.; Pett-Ridge, J.; Kleber, M. Long-Term Litter Decomposition Controlled by Manganese Redox Cycling. Proc. Natl. Acad. Sci. USA 2015, 112, E5253-E5260. [CrossRef]

138. Alguacil, M.D.; Torres, M.P.; Montesinos-Navarro, A.; Roldan, A. Soil Characteristics Driving Arbuscular Mycorrhizal Fungal Communities in Semiarid Mediterranean Soils. Appl. Environ. Microbiol. 2016, 82, 3348-3356. [CrossRef]

139. Collins, R.N.; Kinsela, A.S. Pedogenic Factors and Measurements of the Plant Uptake of Cobalt. Plant Soil 2011, 339, 499-512. [CrossRef]

140. Banerjee, P.; Bhattacharya, P. Investigating Cobalt in Soil-Plant-Animal-Human System: Dynamics, Impact and Management. J. Soil Sci. Plant Nutr. 2021, 21, 2339-2354. [CrossRef]

141. Ahmed, S.; Evans, H.J. Cobalt: A micronutrient Element for the Growth of Soybean Plants under Symbiotic Conditions. Soil Sci. 1960, 90, 205-210. [CrossRef]

142. Akbar, F.M.; Zafar, M.; Hamid, A.; Ahmed, M.; Khaliq, A.; Khan, M.R.; Rehman, Z.U. Interactive Effect of Cobalt and Nitrogen Growth on Growth, Nodulation, Yield and Protein Content of Field Grown Pea. Hortic. Environ. Biotechnol. 2013, 54, 465-474. [CrossRef]

143. Wilson, S.B.; Hallsworth, E.G. Studies on the Nutrition of Forage Legumes: IV The Effect of Cobalt on the Growth and Nodulated and Non-Nodulated Trifolium Subterraneum. Plant Soil 1965, 2, 260-279. [CrossRef]

144. Warren, M.J.; Raux, E.; Schubert, H.L.; Escalante-Semerena, J.C. The Biosynthesis of Adenosylcobalamin (Vitamin B12). Nat. Prod. Rep. 2002, 19, 390-412. [CrossRef]

145. Zhang, Y.; Rodionov, D.A.; Gelfand, M.S.; Gladyshev, V.N. Comparative Genomic Analyses of Nickel, Cobalt and Vitamin B12 Utilisation. BMC Genom. 2009, 10, 78. [CrossRef]

146. Rod, N.K.; Gudadhe, N.N.; Karmakar, N.; Mehta, P.V.; Narwade, A.V. Cobalt Chloride Enhances Crop Duration, Increases Production, and Productivity of Chickpea. J. Plant Nutri. 2019, 42, 40-57. [CrossRef]

147. Amir, H.; Pineau, R. Relationships between Extractable Ni, Co, and Other Metals and Some Microbiological Characteristics in Different Ultramafic Soils from New Caledonia. Aust. J. Soil Res. 2003, 41, 215-228. [CrossRef]

148. Amir, H.; Pineau, R. Release of Ni and Co by Microbial Activity in New Caledonian Ultramafic Soils. Can. J. Microbiol. 2003, 49, 288-293. [CrossRef]

149. Okamoto, S.; Eltis, L.D. The Biological Occurrence and Trafficking of Cobalt. Metallomics 2011, 3, 963-970. [CrossRef]

150. Gikas, P. Single and Combined Effects of Nickel (Ni(II)) and Cobalt (Co(II)) Ions on Activated Sludge and on Other Aerobic Microorganisms: A Review. J. Hazard. Mater. 2008, 159, 187-203. [CrossRef]

151. Quantin, C.; Becquer, T.; Rouiller, J.H.; Berthelin, J. Oxide Weathering and Trace Metal Release by bacterial Reduction in a New Caledonia Ferralsol. Biogeochemistry 2001, 53, 323-340. [CrossRef]

152. Chaudhari, D.; Rangappa, K.; Das, A.; Layek, J.; Basavaraj, S.; Kandpal, B.K.; Shouche, Y.; Rahi, P. Pea (Pisum Sativuml.) Plant Shapes its Rhizosphere Microbiome for Nutrient Uptake and Stress Amelioration in Acidic Soils of the North-East Region of India. Front. Microbiol. 2020, 11, 968. [CrossRef] [PubMed]

153. Inaba, S.; Takenaka, C. Changes in Chemical Species of Copper Added to Brown Forest Soil in Japan. Water Air Soil Pollut. 2005, 162, 285-293. [CrossRef]

154. Schoffer, J.T.; Sauve, S.; Neaman, A.; Ginocchio, R. Role of Leaf Litter on the Incorporation of Copper-Containing Pesticides into Soils under Fruit Production: A Review. J. Soil Sci. Plant Nutr. 2020, 10, 990-1000. [CrossRef]

155. Klevay, L.M. Is the Western Diet Adequate in Copper? J. Trace Elem. Med. Biol. 2011, 25, 204-212. [CrossRef]

156. Jenkins, S.N.; Murphy, D.V.; Waite, I.S.; Rushton, S.P.; O'Donnell, A.G. Ancient Landscapes and the Relationship with Microbial Nitrification. Sci. Rep. 2016, 6, 30733. [CrossRef]

157. Mishra, S.; Keswani, C.; Abhilash, P.C.; Fraceto, L.F.; Singh, H.B. Integrated Approach of Agri-Nanotechnology: Challenges and Future Trends. Front. Plant Sci. 2017, 8, 471. [CrossRef]

158. Simonin, M.; Colman, B.P.; Tang, W.Y.; Judy, J.D.; Andersono, S.M.; Bergemanno, C.M.; Rocca, J.D.; Unrine, J.M.; Cassar, N.; Bernhardt, E.S. Plant and Microbial Response to Repeated $\mathrm{Cu}(\mathrm{OH})_{2}$ Nanopesticide Exposures Under Different Fertilization Levels in an Agro-Ecosystem. Front. Microbiol. 2018, 9, 1769. [CrossRef]

159. Zhao, S.Y.; Su, X.X.; Wang, Y.Y.; Yang, X.Y.; Bi, M.; He, Q.; Chen, Y. Copper Oxide Nanoparticles Inhibited Denitrifying Enzymes and Electron Transport System Activities to Influence Soil Denitrification and $\mathrm{N}_{2} \mathrm{O}$ Emission. Chemosphere 2020, 245, 125394. [CrossRef]

160. Adak, A.; Prasanna, R.; Babu, S.; Bidyarani, N.; Verma, S.; Pal, M.; Shivay, Y.S.; Nain, L. Micronutrient Enrichment Mediated by Plant-Microbe Interactions and Rice Cultivation Practices. J. Plant Nutr. 2016, 39, 1216-1232. [CrossRef]

161. Keiblinger, K.M.; Schneider, M.; Gorfer, M.; Paumann, M.; Deltedesco, E.; Berger, H.; Jochlinger, L.; Mentler, A.; ZechmeisterBoltenstern, S.; Soja, G.; et al. Assessment of Cu Applications in Two Contrasting Soil-Effects on Soil Microbial Activity and Fungal Community Structure. Ecotoxicology 2018, 27, 217-233. [CrossRef] 